\title{
An I Pilus-determining R Factor with Anomalous Compatibility Properties, Mobilizing a Gentamicin-resistance Plasmid
}

\author{
By NAOMI DATTA AND R. W. HEDGES \\ Department of Bacteriology, Royal Postgraduate Medical School, \\ Du Cane Road, London, WI2 o HS
}

(Received 4 December 1972; revised 16 February 1973)

\begin{abstract}
SUMMARY
An R factor complex, JR66, consisted of JR66a, a self-transmissible plasmid conferring resistance to streptomycin and kanamycin and capable of mobilizing JR66b: JR66b was a non-self-transmissible plasmid conferring resistance to gentamicin, streptomycin, tetracycline, chloramphenicol, kanamycin and sulphonamides. It was a member of compatibility group FII. JR66a, which determined I pili, was incompatible with members of two distinct groups, I and B. Plasmids of both these groups were shown to determine I pili.
\end{abstract}

\section{INTRODUCTION}

An $\mathrm{R}$ factor complex conferring resistance to multiple antibiotics, including gentamicin, was derived from a strain of Klebsiella pneumoniae isolated in Washington D.C. (Martin, Ikari, Zimmerman \& Waitz, I97I). Benveniste \& Davies (I97I) showed that gentamicin resistance determined by this $\mathrm{R}$ factor complex (JR66) was mediated by a gentamicinadenylating enzyme. The mechanism appeared to be the same as that determined by $f_{i}-\mathrm{R}$ factors identified in France (J. Davies quoted by Witchitz \& Chabbert, 197I ; Witchitz \& Chabbert, 1972).

Since we had recently investigated the compatibility properties of the French gentamicin-R factors (Datta \& Hedges, I972b) we decided to compare these plasmids with JR66.

Transfer of JR66 between strains of Escherichia coli K I 2 indicated that there were were two $\mathrm{R}$ factors. One, JR66a, conferring resistance to streptomycin and kanamycin (SK), was efficiently transmitted. This $\mathrm{R}$ factor, which determined I pilus production, showed unique compatibility properties, described in this paper.

The other resistances were transmitted with markedly lower efficiency and never without JR66a (Martin et al. I97I; J. Davies, personal communication; and our own observations). We shall show that the gentamicin resistance was determined by a non-self-transmissible plasmid, JR66b, of the FII compatibility group (Hedges \& Datta, 1972).

\section{METHODS}

Bacterial strains. All experiments were in strains of Escherichia coli $\mathrm{K} 12 ; \mathrm{w} 677, \mathrm{~J} 53, \mathrm{~J} 62$, $\mathrm{HfrC}$ (Clowes \& Hayes, 1968) and E. coli C (Bertani \& Weigle, I953).

Plasmids. 'Standard' plasmids of various compatibility groups are listed in Table I. In addition, RI and R296 which specify F-like and I-like pili respectively (Lawn, Meynell. Meynell \& Datta, 1967) were used as controls in experiments to show multiplication of sex-specific phages. 
Table I. Standard plasmids of the compatibility groups studied

$\begin{array}{lll}\text { No. } & \begin{array}{c}\text { Compatibility } \\ \text { group }\end{array} & \text { Resistance* } \\ \text { R386 } & \text { FI } & \text { T } \\ \text { RI-I } & \text { FII } & \text { A, S, C, Su } \\ \text { RI36 } & \text { FII } & \text { T } \\ \text { ColB-K98 } & \text { FIII } & \text { T } \\ \text { RI24 } & \text { FIV } & \text { S, T } \\ \text { R64 } & \text { I } & \text { A, S, T } \\ \text { R64-I } & \text { I } & \text { A, S, T, Su } \\ \text { R46 } & \text { N } & \text { A, T, K } \\ \text { RP4 } & \text { P } & \text { Su, Tp } \\ \text { R388 } & \text { W } & \text { A, S } \\ \text { R40I } & \text { T } & \text { A, K, Su } \\ \text { R40a } & \text { C } & \text { A, C, Su, Gk } \\ \text { R57b } & \text { C } & \text { S, Tp } \\ \text { R483 } & \text { B } & \text { S, Su } \\ \text { R300 } & \text { T } & \text { T, Su } \\ \text { RAI } & \text { A } & \text { S, C } \\ \text { R387 } & \text { X } & \text { A, S } \\ \text { R6K } & \text { X } & \end{array}$

\author{
Reference \\ Dennison, 1972 \\ Coetzee et al. 1972 \\ Hedges \& Datta, 1972 \\ Frydman \& Meynell, 1969 \\ Hedges \& Datta, 1972 \\ Lawn et al. 1967 \\ Datta et al. 197 I \\ Datta \& Hedges, I97I \\ Datta et al. 1971 \\ Datta \& Hedges, 1972 a \\ Coetzee et al. 1972 \\ Datta \& Hedges, $1972 b$ \\ Witchitz \& Chabbert, 1972 \\ Hedges, Datta \& Fleming, 1972 \\ Lawn et al. 1967 \\ Hedges \& Datta, 197 I \\ Hedges \& Datta, I97I \\ Kontomichalou, Mitani \& \\ Clowes, 1970
}

* A, ampicillin; S, streptomycin; T, tetracycline; C, chloramphenicol; K, kanamycin; Su, sulphonamides ; $\mathrm{Tp}$, trimethoprim; Gk, gentamicin with low-level kanamycin resistance.

Phages. MS2 (Davis, Strauss \& Sinsheimer, 196I) which adsorbs to F pili; If (Meynell \& Lawn, 1968) which adsorbs to I pili.

Media. Nutrient broth was Oxoid no. 2 (CM67); nutrient agar was the same, solidified with $\mathrm{I} \cdot 2 \%$ New Zealand agar. MacConkey agar was Oxoid $\left(\mathrm{CM}_{7} \mathrm{~b}\right)$. Minimal salts agar was as described by Clowes \& Hayes (1968).

Transfer of $R$ factors was as described by Datta et al. (1971). Where no transfer was detected at $\mathrm{I} h$ after mixture, cultures were incubated overnight and retested.

Compatibility of $R$ factors was tested as described by Coetzee, Datta \& Hedges (I972).

fi character of plasmids was tested as described by Coetzee et al. (1972).

Phage increase was measured by methods described by Datta, Lawn \& Meynell (1966) and Datta et al. (197I). Increase of phage MS2 in a bacterial culture indicated the presence of $\mathrm{F}$ pili; increase of phage If $\mathrm{I}$ indicated the presence of I pili.

\title{
Separation of JR66a and JR66b
}

\section{RESULTS}

I. Conjugal transfer. When selection was made for resistance to either streptomycin (S) or kanamycin (K), resistances to both drugs (SK) were always co-transferred with an efficiency of about $5 \times 10^{-3}$. When selection was made for genetamicin $(\mathrm{G})$, chloramphenicol $(\mathrm{C})$ or tetracycline $(\mathrm{T})$ resistance, all resistance markers [GSTCK and sulphonamide (Su)] were co-transferred with efficiency of about $\mathrm{IO}^{-5}$. Every exconjugant clone carrying these resistances could, in turn, transfer SK resistance separately from, and at higher frequency than, the complete pattern. We inferred that SK resistance was determined by one plasmid (JR66a) whilst the other resistances were determined by another plasmid (JR66b), which might be non-self-transmissible.

2. Transfection. To isolate a culture carrying JR66b alone, DNA was extracted from w677 (JR66), and mixed with Escherichia coli $\mathrm{C}$ made competent for transfection by the 
Table 2. Compatibility of JR66a

Mating mixtures were incubated for i h at $37^{\circ} \mathrm{C}$. Frequency of transfer was calculated per input donor cell.

\begin{tabular}{|c|c|c|c|c|}
\hline Donor & Recipient & Selection & $\begin{array}{l}\text { Frequency } \\
\text { of transfer }\end{array}$ & $\begin{array}{l}\text { Exconjugant clones tested for } \\
\text { presence of each plasmid }\end{array}$ \\
\hline w677 (JR66a) & $\begin{array}{l}\text { J53 } \\
\text { J53 (R64) } \\
\text { J53 (R64-I }) \\
\text { J53 (R483) }\end{array}$ & $\begin{array}{l}\mathrm{K} \\
\mathrm{K} \\
\mathrm{K} \\
\mathrm{K}\end{array}$ & $\begin{array}{l}4 \times 10^{-3} \\
1 \times 10^{-3} \\
6 \times 10^{-4} \\
3 \times 10^{-3}\end{array}$ & $\begin{array}{l}\text { I } 8 / 20 \text { JR } 66 \mathrm{a} \text { only, } 2 / 20 \text { both present, unstable } \\
\text { I 4/20 JR66a only, } 6 / 20 \text { both present, unstable } \\
\text { I6/20 JR } 66 \text { a only, } 4 / 20 \text { both present, stable* }\end{array}$ \\
\hline J53 (R64) & $\begin{array}{l}\text { w677 } \\
\text { w677 (JR66a) }\end{array}$ & $\begin{array}{l}\mathrm{T} \\
\mathrm{T}\end{array}$ & $\begin{array}{l}1 \times 10^{-3} \\
1 \times 10^{-5}\end{array}$ & 20/20 R64 only $\quad-$ \\
\hline $\mathrm{J} 53$ (R64) & J53 $\left(\mathrm{R}_{4} 83\right)$ & $\mathrm{T}$ & $\mathrm{I} \times \mathrm{IO}^{-3}$ & $20 / 20$ both present, stable $\dagger$ \\
\hline $\mathrm{J}_{53}\left(\mathrm{R}_{4} 83\right)$ & $\begin{array}{l}\text { J62 } \\
\text { w677 (JR66a) }\end{array}$ & $\begin{array}{l}\text { Tp } \\
\text { Tp }\end{array}$ & $\begin{array}{l}1 \times 10^{-3} \\
1 \times 10^{-3}\end{array}$ & 19/20 R483 only, $1 / 20$ both present, unstable \\
\hline
\end{tabular}

* Trimethoprim resistance non-transmissible (see text).

$\div$ Each R factor separately transmissible.

JR66a co-existed stably with all other plasmids tested: R386, RI36, ColB-K98, Ri24, R46, RP4, R388, R40I, R40a, R57b, R300, RAI, R387, R6K.

method of Mandel \& Higa (I970) modified by A. E. Jacob and S. J. Laver (to be published). Clones of $E$. coli $\mathrm{C}$ were isolated on plates containing gentamicin, chloramphenicol or tetracycline. They were resistant to the same drugs (GSTCKSu) as the donor. Since these resistances were not transmissible by conjugation to $E$. coli $\mathrm{KI} 2$, we conclude that the transfectants carried JR66b only, which was non-self-transmissible.

\section{Compatibility of JR66a}

JR66a was compatible with R factors of all groups tested except with I plasmids R64 and R64-I and with R483, the prototype of compatibility group B(Table 2). JR66a was susceptible to elimination by any of these three plasmids and capable of eliminating'each of them. When JR66a was transferred to a recipient carrying both R64 and R483, both resident plasmids were eliminated. Thus JR66a belonged to two compatibility groups, I and B. Introduction of JR66a to J53 (R483) usually eliminated the latter, but in a minority of clones trimethoprim resistance was retained. From these clones trimethoprim resistance was not transmissible, although JR66a was transmissible with normal frequency.

From double $\mathrm{R}^{+}$cultures, carrying JR66a and standard $f^{-} \mathrm{R}$ factors, transfer of each plasmid occurred separately and at normal rates, with one exception. J53 (JR66a)(RP4) transferred JR66a at normal frequency but RP4 at a frequency approximately Ioo-fold lower than normal. When selection was made for transfer of ampicillin resistance from this double, a minority of exconjugants carried recombinant plasmids with the resistance patterns ASK or AS.

\section{Recombination between JR66a and the I-like $R$ factor R64-I}

When JR66a (resistance pattern SK) was transferred to a recipient carrying R64-I (resistance pattern AST) the resident R factor was eliminated from the majority ( $14 / 20$ ) of purified exconjugants. The minority $(6 / 20)$ were unstable doubles which segregated not only the parental $\mathrm{R}$ factors but also plasmids conferring the following resistance patterns: TSK, ASK, AS (Table 2). 
Table 3. Compatibility of the gentamicin resistance determinant (JR66b)

$\begin{array}{clccc}\text { Donor } & \text { Recipient } & \text { Selection } & \begin{array}{c}\text { Frequency of } \\ \text { transfer }\end{array} & \begin{array}{c}\text { Exconjugant clones tested } \\ \text { for presence of each plasmid }\end{array} \\ \text { W677 (JR66) } & \mathrm{J} 53 & \mathrm{G} & \mathrm{1} \times 10^{-5} & - \\ \mathrm{J} 53 & \mathrm{~T} & 3 \times 10^{-5} & - \\ \mathrm{J53}(\mathrm{RI}-\mathrm{I}) & \mathrm{J} 53(\mathrm{RI}-\mathrm{I}) & \mathrm{G} & 5 \times 10^{-6} & 38 / 38 \mathrm{JR} 66 \text { only } \\ & \text { W677 } & \mathrm{A} & \mathrm{I} \times 10^{-3} & - \\ & \text { W677 (JR66) } & \mathrm{A} & 5 \times 10^{-4} & \text { 32/32 RI-I and JR66a } \\ \text { (JR66b eliminated) }\end{array}$

JR66b co-existed stably with all other plasmids tested: R64-I, R46, RP4, R388, R40a, R57b, R40I, R6K, R483.

Table 4. Transfer from doubles

\begin{tabular}{|c|c|c|c|c|}
\hline Donor & Recipient & Selection & $\begin{array}{l}\text { Frequency } \\
\text { of transfer }\end{array}$ & $\begin{array}{l}\text { Exconjugants tested for the presence } \\
\text { of each plasmid }\end{array}$ \\
\hline $\mathrm{J}_{53}(\mathrm{JR} 66 \mathrm{a})\left(\mathrm{R}_{3} 86\right)$ & $\mathrm{J} 62$ & $\begin{array}{l}\mathbf{K} \\
\mathrm{T}\end{array}$ & $\begin{array}{l}5 \times 10^{-3} \\
\mathrm{I} \times 10^{-3}\end{array}$ & $\begin{array}{l}\text { 20/20 JR66a only } \\
20 / 20 \text { R } 386 \text { only }\end{array}$ \\
\hline J53 (R386) & $\mathrm{J} 62$ & $\mathrm{~T}$ & $>\mathrm{I}$ & - \\
\hline J53 (JR66a) (RI36) & $\mathrm{J} 62$ & $\begin{array}{l}\mathrm{K} \\
\mathrm{T}\end{array}$ & $\begin{array}{l}5 \times 10^{-3} \\
1 \times 10^{-4}\end{array}$ & $\begin{array}{l}\text { 20/20 JR } 66 \text { a only } \\
\text { r } 9 / 20 \text { RI } 36 \text { only, I/20 both present }\end{array}$ \\
\hline J53 $(\operatorname{RI36})$ & $\mathrm{J} 62$ & $\mathrm{~T}$ & $1 \times 10^{-3}$ & - \\
\hline J53 (JR66a) (ColB-K98) & 562 & K & $8 \times 10^{-3}$ & $20 / 20$ JR66a only \\
\hline J53 (JR66a) (R I 24) & $\mathrm{J} 62$ & $\begin{array}{l}\mathrm{K} \\
\mathrm{T}\end{array}$ & $\begin{array}{l}5 \times 10^{-3} \\
2 \times 10^{-5}\end{array}$ & $\begin{array}{l}\text { 20/20 JR66a only } \\
\text { I6/20 RI24 only, } 4 / 20 \text { both present }\end{array}$ \\
\hline J53 (RI24) & $\mathrm{J} 62$ & $T$ & $2 \times 10^{-3}$ & - \\
\hline
\end{tabular}

\section{Compatibility of JR66b}

The efficiency of transfer of JR66b, mobilized by JR66a, was not reduced by any resident plasmid in the recipient. JR66 b was compatible with all plasmids tested (including R64-I and R483) except RI-I, a member of compatibility group FII. We conclude that JR66b belongs to group FII (Table 3 ).

\section{fi character of JR66}

HfrC (JR66a) was not visibly lysed by male-specific phage MS2. The $\mathrm{ft}^{+}$character of JR66a was retained after co-existence with plasmids of all four known F-like compatibility groups (R386: FI; RI36: FII; ColB-K98: FIII; R 124: FIV [Hedges \& Datta, 1971]). The presence of JR66a in donors repressed the transfer rate of all the F-piliated $R$ factors (i.e. R386, Ri36, Ri24) (Table 4).

\section{Sex pili}

W677 (JR66), w677 (JR66a) and J53 (R483) did not support multiplication of phage MS2. All these three cultures supported the multiplication of If $\mathrm{I}$. When R483 was transferred to cultures of Escherichia coli $\mathrm{K} I 2$ carrying I plasmids derepressed for pilus synthesis (R64drdII, Ri44drd3, Ri63drd7, ColIdrd and Idrdr6) (Meynell, I972) the incoming and resident plasmids co-existed stably. All four doubles were visibly lysed by phage If I, i.e. R483 did not repress I pilus synthesis in trans. 
I)ISCUSSION

JR66 was of interest to us because it determines a gentamicin-adenylating enzyme analogous to that determined by $\mathrm{R}$ factors identified in France (J. Davies, personal communication; Witchitz \& Chabbert, 1971, 1972). These latter $\mathrm{R}$ factors are $f^{-}$and botong to compatibility group C (Datta \& Hedges, 1972 b). In fact, neither of the constituent plasmids of JR66 was a member of group $C$. The gentamicin-resistance determinant was carried by a non-self-transmissible F II plasmid. Thus what is occurring is not pandemic spread of a single plasmid clone. Genes determining gentamicin-inactivating enzymes (Benveniste \& Davies, I97I) need not, however, have evolved separately in the two areas. We have observed recombination between $\mathrm{C}$ plasmids and the fertility factor, $\mathrm{F}$, of Escherichia coli $\mathrm{K} 12$ (Datta \& Hedges, unpublished): it is not unlikely that exchange of markers has occurred in nature between $\mathrm{C}$ and F-like plasmids.

The plasmid JR66a, which accompanied and mobilized the gentamicin resistance determinant, had unusual properties. It was $f i^{\text {r }}$ but produced I pili, not $\mathrm{F}$ pili. In this it resembled R62 (Lawn et al. 1967) and several R factors described by Grindley \& Anderson (1971). JR66a in donors repressed the transfer of all F-like R factors tested, even R386 which was not repressible by ordinary F-like $f+$ plasmids (Dennison, 1972) (Table 4). The nature of the $\mathrm{fi}^{+}$character of JR66a is thus different from that of ordinary F-like plasmids such as colBK98 (Frydman \& Meynell, 1969) and R538-I (Romero \& Meynell, 1969; Dennison, 1972), and seems to resemble that of R62 (Meynell, 1973).

JR66a resembled plasmids of the I group (e.g. R64) in some respects but differed from them in others. Its similarities to R64 were: (i) pilus specificity - JR66a produced pili which served as receptors for phage If 1 (as shown by multiplication of the phage in JR66a" cultures); (ii) compatibility - the two plasmids were incompatible; (iii) genetic homology - this was indicated by the generation of recombinant plasmids after transfer of JR66a into a culture containing R64-I; (iv) interaction with RP4-JR66a, like R64 (Datta et al. 197I) inhibited the transfer of $\mathrm{RP}_{4}$ from $\mathrm{R}^{+}$strains and also like $\mathrm{R}_{4}$, it recombined with $\mathrm{RP}_{4}$.

On the other hand, JR66a differed from R64, and other members of the group, in the following ways: (i) unilateral exclusion - whereas the presence of a typical I-like plasmid in a recipient markedly reduces the rate of transfer of an incoming I plasmid, JR66a efficiently excluded R64 but was only slightly excluded by R64 (Table 2); (ii) incompatibility with R463-typical I plasmids (exemplified by R64 and R144) co-exist stably with R483, a member of compatibility group B (Hedges, Datta \& Fleming, 1972).

Since JR66a was incompatible with both R64 and R483, it belonged to two compatibility groups I and B. The group B plasmid R 483 , like JR66a and typical I group plasmids, determines I pili. Pilus synthesis by $\mathrm{R}_{4} 83$ appeared to be repressed, since transfer was at normal frequencies and $R 483^{+}$cultures were not visibly lysed by phage If $I$, but there was no repression of pilus production in trans when $\mathrm{R}_{4} 83 \mathrm{co}$-existed with derepressed mutant I plasmids. Introduction of JR66a usually eliminated $R 483$ but in a minority of JR66a exconjugants, trimethoprim resistance was retained. This character was non-transmissible, indicating that $\mathrm{R}_{4} 83$ was not in its normal cytoplasmic state. Whether the trimethoprim-resistance determinants had become integrated into the chromosome or some other replicon, or whether R483 was still replicating autonomously but with defective compatibility and transfer functions, we have not discovered.

A plasmid incompatible with two groups of plasmids, themselves compatible, may be explained in either of two ways. It may have resulted from fusion of plasmids of two groups. An example is that produced by recombination between a ColV plasmid (compatibility 
group FI) and an R factor, R538-I drd (compatibility group F II), which was incompatible with plasmids of both groups (Cooper, 1971). Alternatively, JR66a may represent an ancestral form of plasmids of groups I and B, which have diverged in evolution, becoming compatible with one another. Supporting the latter model is the fact that plasmids of both groups (I and B) determine I pili.

We thank Julian Davies for cultures containing JR66 and Elinor Meynell for antisera to phages MS2 and If I. We are also grateful to Alan Jacob and Susan Laver for their advice and assistance in transfection experiments.

\section{REFERENCES}

BeNVENISTE, R. \& DAVIES, J. (I97I). R-factor mediated gentamicin resistance: a new enzyme which modified aminoglycoside antibiotics. FEBS Letters $\mathbf{1 4}, 293-296$.

BeRTANI, G. \& WeIGLE, J. J. (I953). Host controlled variation in bacterial viruses. Journal of Bacteriology 65, II $3-I 2 I$.

Clowes, R. C. \& Hayes, W. (1968). Experiments in Microbial Genetics. Oxford and Edinburgh: Blackwell Scientific Publications.

Coetzee, J. N., Datta, N. \& Hedges, R. W. (1972). R factors from Proteus rettgeri. Journal of General Microbiology 72, 543-552.

COOPER, P. (I97I). Interaction of a colicinogenic factor with a resistance factor and with the fertility factor $\mathrm{F}$ in Escherichia coli $\mathrm{K}-\mathrm{I} 2$. Genetical Research $\mathbf{7} 7$, I5I-I 59.

Datta, N. \& Hedges, R. W. (197I). Compatibility groups among $f^{-}$R factors. Nature, London 234, $222-$ 223.

Datta, N. \& Hedges, R. W. (1972a). Trimethoprim resistance conferred by W plasmids in Enterobacteriaceae. Journal of General Microbiology 72, 349-355.

Datta, N. \& Hedges, R. W. (1972 b). R factors identified in Paris, some conferring gentamicin resistance, constitute a new compatibility group. Annales de l'Institut Pasteur I23, 849-852.

Datta, N., Hedges, R. W., Shaw, E. J., Sykes, R. B. \& Richmond, M. H. (1971). Properties of an R factor from Pseudomonas aeruginosa. Journal of Bacteriology 108, 1244-1249.

DAtTA, N., LAWN, A. M. \& MEYNell, E. (I966). The relationship of F type pilation and F phage sensitivity to drug resistance transfer in $\mathrm{R}^{+} \mathrm{F}^{-}$Escherichia coli $\mathrm{KI}$ 2. Journal of General Microbiology 45, 365-376.

Davis, J. E., Strauss, J. H. \& Sinsheimer, R. L. (ig61). Bacteriophage MS2 : another RNA phage. Science, New York 134, 1427.

DenNison, S. (1972). Naturally occurring R factor, derepressed for pilus synthesis, belonging to the same compatibility group as the sex factor F of Escherichia coli $\mathrm{K}-\mathrm{I} 2$ 2. Journal of Bacteriology 109, 4I 6-422.

Frydman, A. \& MeYnell, E. ( 1969). Interactions between de-repressed F-like R factors and wild type colicin B factors: superinfection immunity and repressor susceptibility. Genetical Research 14, 31 5-332.

GrindLEy, J. M. \& ANDERson, E. S. (I97I). I-like resistance factors with the $f^{+}$character. Genetical Research I7, 267-27I.

Hedges, R. W. \& Datta, N. (1971). $f^{-}$R factors giving chloramphenicol resistance. Nature, London 234 , 220-22I.

HEDGes, R. W. \& Datta, N. (1972). R I24, and $f^{+} \mathrm{R}$ factor of a new compatibility class. Journal of General Microbiology 7 $\mathbf{x}, 403-405$.

Hedges, R. W., Datta, N. \& Fleming, M. P. (1972). R factors conferring resistance to trimethoprim but not sulphonamides. Journal of General Microbiology 73, 573-575.

Kontomichalou, P., Mitani, M. \& Clowes, R. C. (1970). Circular R-factor molecules controlling penicillinase synthesis, replicating in Escherichia coli under either relaxed or stringent control. Journal of Bacteriology 104, 34-44.

Lawn, A. M., Meynell, E., Meynel.l, G. G. \& Datta, N. (1967). Sex pili and the classification of sex factors in the Enterobacteriaceae. Nature, London 216, 343-346.

MANDEL, M. \& HIGA, A. (I970). Calcium-dependent bacteriophage DNA infection. Journal of Molecular Biology 53, I59-162.

Martin, C. M., IKari, N. S., Zimmerman, J. \& Waitz, A. J. (197I). A virulent nosocomial Klebsiella with a transferable $\mathrm{R}$ factor for gentamicin: emergence and suppression. Journal of Infectious Disease $\mathbf{1 2 4}$ (Supplement), 24-29. 
MeynelL, E. (1973). A pseudo- $f^{+}$I-like sex factor, R62(I), selective for increased pilus synthesis. Journal of Bacteriology (in the Press).

Meynell, G. G. (1972). Bacterial Plasmids. London: Macmillan.

MeYneLL, G. G. \& LAWN, A. M. (1968). Filamentous phages specific for the I sex factor. Nature, London 217, $1184-1186$.

Romero, E. \& MeYNell, E. (1969). Covert $f i$ R factors in $f^{\perp} \mathrm{R}^{+}$strains of bacteria. Journal of Bacteriology 97 , $780-786$.

WitchitZ, J.-L. \& Chabbert, Y.-A. ( I97I). Résistance transférable à la gentamicine. I. Expression du charactère de résistance. Annales de l'Institut Pasteur 121, 733-742.

WitchitZ, J.-L. \& Chabbert, Y.-A. (I972). Résistance transférable à la gentamicine. II. Transmission et liaisons du charactère de résistance. Annales de l'Institut Pasteur 122, 367-378. 